\title{
TP53 Gene Mutation
}

National Cancer Institute

\section{Source}

National Cancer Institute. TP53 Gene Mutation. NCI Thesaurus. Code C118396.

A change in the nucleotide sequence of the TP53 gene. 